\title{
In vitro and molecular characterization using ISSR markers of Glycyrrhiza glabra L.
}

\author{
Asmaa AbD El-Hameid ${ }^{1 *}$, Zakia Abo El-KHeIR ${ }^{2}$, Mohamed Abdel-HadY $^{3}$, WafaA Helmy $^{4}$ \\ ${ }^{1}$ Botany Department, National Research Center, Dokki, Cairo, Egypt \\ ${ }^{2}$ Department of Botany \& Microbiology, Faculty of Science, Al-Azhar University, Cairo, Egypt \\ ${ }^{3}$ Botany Department, National Research Centre, Dokki, Giza, Egypt \\ ${ }^{4}$ Chemistry of Microbial and Natural Products Department, Pharmaceutical and Drug Industries Research Division, \\ National Research Centre, Dokki, Cairo, Egypt
}

\begin{abstract}
Licorice (Glycyrrhiza glabra) is the rhizome and root known as sweet wood. Two varieties of Glycyrrhiza (var. glabra and var. glandulifera) were studied. The major objective of this study was to establish callus induction on Glycyrrhiza and to assess the molecular genetic variation between the mother plants and their calli using ISSR markers. Calli were formed from leaves of Glycyrrhiza cultured on Murashige and Skoog's medium supplemented with combinations of various concentrations of auxins and cytokinins. The highest callus induction and callus fresh weight of 2 varieties tested were obtained on a medium containing $0.5 \mathrm{mg} / 12$,4-dichlorophenoxy acetic acid with $1 \mathrm{mg} / 1$ 1-naphthalene acetic acid and $0.5 \mathrm{mg} / 1$ kinetin. Genomic DNA was isolated from plants and calli using cetyltriethyl ammonium bromide method and amplified by PCR using ISSR primers. The results showed the presence of genetic variations at the DNA level during in vitro culture between callus and mother plants.
\end{abstract}

Key words: Glycyrrhiza glabra L., callus induction, genomic DNA, ISSR makers

\begin{abstract}
Abbrevitions
ISSR - Inter simple sequence repeats

PCR - Polymerase chain reaction

CTAB - Cetyltriethyl ammonium bromide

NAA - 1-naphthalene acetic acid

Kin - Kinetin

MS - Murashige and Skoog's medium

EDTA - Ethylenediaminetetraacetic acid

dNTP - Deoxyribonucleotide triphosphate
\end{abstract}

SSR - Simple sequence repeats

DNA - Deoxyribonucleic acid

2,4-D - 2,4-dichlorophenoxy acetic acid

BA - 6-benzylaminopurine

GZ - Glycyrrhizin

PGRs - Plant growth regulators

TAE - Tris-acetate-EDTA

\section{Introduction}

Glycyrrhiza known as Licorice belongs to family Leguminosae, genus Glycyrrhiza, which includes about 30 species. Licorice has been recognized as an important medicinal herb since ancient times (Shibata, 2000). Glycyrrhiza name comes from Greek where "glykos" means "sweet" and "rhiza" means "root". Glycyrrhizin (GZ), a main constituent of licorice (Glycyrrhiza glabra L.) is used for treatment of allergies, chronic hepatitis and other diseases (Koga et al., 2004). GZ in licorice has been shown to be effective in gastric ulcer treatment
(Bennet et al., 1985). Moreover, glycyrrhetinic acid (an aglicone from of glycyrrhizin) has an anti-ulcer and antiinflammatory potential (Yano et al., 1989).

The specific in vitro culture requirements, including auxin/cytokinin concentrations or their relative ratio, are important factors in glycyrrhizin production from callus. Phytohormones such as auxins and cytokinins were reported to be regulators of plant growth and developmental processes such as callus induction, root formation, shoot formation and growth of buds (Mokhtari et al., 2015). Callus induction of G. glabra, G. uralensis and G. inflate

\footnotetext{
*Corresponding author: Botany Department, National Research Center, Dokki, Cairo, Egypt; e-mail: as_raafat4a@yahoo.com
} 
have been achieved on Murashige and Skoog (MS) medium supplemented with $(0.5-1 \mathrm{mg} / \mathrm{l})$ auxins (NAA and 2,4-D) and (0.5-1 mg/l) cytokinins (BA and Kin) i.e. combinations of NAA and BA, 2,4-D and BA, 2,4-D and Kin series (Wongwicha et al., 2008). The efficient in vitro regeneration system via callus phase has been developed using various plant growth regulators (auxin and cytokinins). The best callus induction was reported on MS medium with the combination of $2,4-\mathrm{D}(1.5 \mathrm{mg} / \mathrm{l})$ with BA $(0.5 \mathrm{mg} / \mathrm{l})$; where a viable organogenic green compact nodular callus from the basal part of the explant has been obtained (Abirami and Kumar, 2013).

The oxidation of phenolic compounds in Glycyrrhiza glabra produced a brown colored substances during tissue culture that led to browning and necrosis of callus. Several tissue culture studies of these plants were investigated to control this phenomena by using absorbents and antioxidants (Jain et al., 2008; Habibi et al., 2009; Khosroushahi et al., 2011; Vijayalakshmi and Shourie, 2016)

Molecular markers have proved to be the best tool for investigating and evaluating the genetic fidelity of in vitro derived callus. The ISSR markers have been widely used to assess such variations (Kondo et al., 2007). The genetic markers have also been used to identify Glycyrrhiza species. The objectives of this study were to determine the response of 2 varieties of Glycyrrhiza (var. glabra and var. glandulifera) to callus induction and to evaluate the molecular genetic variations at the DNA level during in vitro culture.

\section{Materials and methods}

\section{Callus induction}

\section{Explant source and sterilization}

The experiments were carried out in the Tissue Culture Laboratory, Botany Department, National Research Center (NRC), Cairo, Egypt. Callus cultures were obtained from leaves collected from 2 varieties of Glycyrrhiza glabra (var. glabra and var. glandulifera) grown in field. The explants were washed thoroughly with running tap water for $20 \mathrm{~min}$ and sterilized in $70 \%$ ethanol for $2 \mathrm{~min}$. After that they were washed 4 times with distilled sterilized water and sterilized again with $30 \%$ Clorox solution (containing $5.25 \%$ sodium hypochlorite) with 2 drops of Tween 20 for $20 \mathrm{~min}$ and finally washed with distilled sterilized water. The explants were cultured on MS basal medium (Murashige and Skoog, 1962).

\section{Culture Media and conditions}

Modified MS medium containing different concentrations of auxins and cytokinins as plant growth regulators (PGR) were used as plant media for growth of licorice explants. The treatment scheme is presented in Table 1. The $\mathrm{pH}$ of the medium was adjusted to 5.8 using $1 \mathrm{M}$ $\mathrm{NaOH}$ or $\mathrm{HCl}$, then it was autoclaved at $121^{\circ} \mathrm{C}$ and a pressure of $1.2 \mathrm{~kg} / \mathrm{cm}^{2}$ for $20 \mathrm{~min}$. The cultures of licorice were incubated in a growth chamber in the dark at $25^{\circ} \mathrm{C}$ (irradiance of $25 \mu \mathrm{mol} / \mathrm{m}^{2}$ s provided by cool white fluorescent lamps) for 1 month. The sub-culturing was performed after 4 weeks from incubated culture to avoid production of phenolic compounds, which cause brown coloration in callus. The explants were inoculated into 4 media (as presented in Table 1) in 4 replicates. The calli induction percentage was calculated using the following formula:

$$
\underset{\text { induction [\%] }}{\text { Callus }}=\frac{\text { Number of explants induced calli }}{\text { Total number of explants inoculated }} \times 100 \%
$$

\section{Extraction and purification of genomic DNA}

Extraction and purification of genomic DNA was done according to the protocol by Niu and coworkers (2008). The leaves of licorice $(0.1 \mathrm{~g})$ and the calli tissues $(0.5 \mathrm{~g})$ were ground separately to a fine powder using liquid nitrogen. Cetyltriethyl ammonium bromide (CTAB) extraction buffer (100 mM Tris- $\mathrm{HCl}(\mathrm{pH} 8.0), 1.4 \mathrm{M} \mathrm{NaCl}$, $20 \mathrm{mM}$ EDTA ( $\mathrm{pH} \mathrm{8.0)}$ and $2 \% \mathrm{w} / \mathrm{v}$ CTAB) was used for isolation of genomic DNA from leaves and calli of licorice. The DNA concentration was measured using UV spectrophotometer. The quality of the DNA was checked on $1 \%$ of agarose gel in $0.5 \times$ TAE buffer (10 mMTris$\mathrm{HCl}$ and $0.5 \mathrm{mM}$ EDTA (pH 9.0)).

\section{Inter-simple sequence (ISSR) analysis}

The amplification reaction (PCR) was carried out in 25 $\mu 1$ total reaction mix containing $2 \mu \mathrm{l}(20 \mathrm{ng})$ template DNA, $2.5 \mu \mathrm{l}(2 \mathrm{mM}) \mathrm{dNTPs}, 3 \mu \mathrm{l}(10 \mathrm{pmol})$ primer, $2.5 \mu \mathrm{l}$ (1.5 mM) $\mathrm{MgCl}_{2}, 5 \mu \mathrm{l} 10 \times$ buffer, $0.25 \mu \mathrm{l}(5 \mathrm{U} / \mathrm{ml}) \mathrm{Taq}$ DNA polymerase (Promega, USA) and $9.75 \mathrm{ddH}_{2} \mathrm{O}$. PCR amplification was carried out using Biometra Cycler (Gottingen, Germany). Forty cycles were performed, after an 
Table 1. MS-media supplemented with different growth regulators

at different concentrations for callus induction from leaf explants of Glycyrrhiza glabra

\begin{tabular}{c|c}
\hline $\begin{array}{c}\text { Number } \\
\text { of media }\end{array}$ & MS - media composition \\
\hline 1 & MS $(4.4 \mathrm{~g} / \mathrm{l})+$ Sucrose $(30 \mathrm{~g} / \mathrm{l})+\operatorname{Agar}(7 \mathrm{~g} / \mathrm{l})+1 \mathrm{mg} / \mathrm{l}(\mathrm{NAA})+0.5 \mathrm{mg} / \mathrm{l}(2,4-\mathrm{D})+0.5 \mathrm{mg} / 1(\mathrm{Kin})$ \\
\hline 2 & $\mathrm{MS}(4.4 \mathrm{~g} / \mathrm{l})+\operatorname{Sucrose}(30 \mathrm{~g} / \mathrm{l})+\operatorname{Agar}(7 \mathrm{~g} / \mathrm{l})+1 \mathrm{mg} / \mathrm{l}(\mathrm{NAA})+1 \mathrm{mg} / \mathrm{l}(2,4-\mathrm{D})+0.5 \mathrm{mg} / \mathrm{l}(\mathrm{Kin})$ \\
\hline 3 & $\mathrm{MS}(4.4 \mathrm{~g} / \mathrm{l})+\operatorname{Sucrose}(30 \mathrm{~g} / \mathrm{l})+\operatorname{Agar}(7 \mathrm{~g} / \mathrm{l})+0.5 \mathrm{mg} / \mathrm{l}(\mathrm{NAA})+2 \mathrm{mg} / \mathrm{l}(\mathrm{BA})+0.5 \mathrm{mg} / \mathrm{l}(\mathrm{Kin})$ \\
\hline 4 & $\mathrm{MS}(4.4 \mathrm{~g} / \mathrm{l})+$ Sucrose $(30 \mathrm{~g} / \mathrm{l})+\operatorname{Agar}(7 \mathrm{~g} / \mathrm{l})+1 \mathrm{mg} / \mathrm{l}(\mathrm{NAA})+2 \mathrm{mg} / \mathrm{l}(\mathrm{BA})$ \\
\hline
\end{tabular}

Table 2. List of ISSR primers their sequences and their annealing temperature

\begin{tabular}{|c|c|c|}
\hline Primer & Sequence $\left(5^{\prime}-3^{\prime}\right)$ & $\begin{array}{c}\text { Annealing } \\
\text { temperature } \\
{\left[{ }^{\circ} \mathrm{C}\right]}\end{array}$ \\
\hline 807 & $5^{\prime}$-AGA GAG AGA GAG AGA GT-3' & 50 \\
\hline 810 & $5^{\prime}-$ GAG AGA GAG AGA GAG AT-3' & 50 \\
\hline 823 & $5^{\prime}-\mathrm{TCT}$ СТС ТСТ СТС ТСТ CC- $3^{\prime}$ & 52 \\
\hline 826 & $5^{\prime}-\mathrm{ACA}$ CAC ACA CAC ACA CC- $3^{\prime}$ & 52 \\
\hline 844 & $5^{\prime}-\mathrm{CTC}$ ТСТ СТС ТСТ СТC ТC- $3^{\prime}$ & 55 \\
\hline 848 & $5^{\prime}-\mathrm{CAC}$ ACA CAC ACA CAC AAG- $3^{\prime}$ & 52 \\
\hline SPS1 & $5^{\prime}-\mathrm{GAC}$ GAC GACGAC GAC- $3^{\prime}$ & 52 \\
\hline SPS03 & $5^{\prime}-\mathrm{GAC}$ AGA CAG ACA ACA-3' & 48 \\
\hline SPS08 & $5^{\prime}-\mathrm{GGA}$ GGA GGA GGA- $3^{\prime}$ & 40 \\
\hline SPS9 & $5^{\prime}-\mathrm{CAA}$ CAA CAACAA CAA- $3^{\prime}$ & 38 \\
\hline
\end{tabular}

initial denaturation step for $5 \mathrm{~min}$ at $94^{\circ} \mathrm{C}$. Each cycle consisted of a denaturation step $94^{\circ} \mathrm{C}$ at $30 \mathrm{~s}$, annealing at $45^{\circ} \mathrm{C}$ for $45 \mathrm{sec}$ and extension at $72^{\circ} \mathrm{C}$ for $1 \mathrm{~min}$. The final extension step was performed for $5 \mathrm{~min}$ at $72^{\circ} \mathrm{C}$.

The amplification products were analyzed by electrophoresis in $1 \%$ agarose gel in $0.5 \times$ TBE buffer and detected by ethidium bromide staining. $1 \mathrm{~kb}$ DNA ladder (SibEnzyme Ltd., Russia) was used as molecular size standard. PCR products were visualized by UV transilluminator and photographed with gel documentation system.

From the preliminary screening (data not published), 10 primers amplifying visible bands were selected for further investigations. The tested primers and their sequences are listed in Table 2.

\section{Statistical analysis}

All in vitro cultures experiments were designed according to a completely randomized design. The mean values of different treatments were compared using Duncan's new multiple range test (Duncan, 1955). All experi- ments were conducted in triplicate. Data are reported as mean \pm standard deviation (SD). The amplified DNA polymorphic fragments were calculated for each ISSR primer according to the presence (1) or absence (0) of a band, analyzed using Total Lab (T.L. 120) program. Fragments were arranged according to their molecular size.

\section{Results and discussion}

\section{Callus induction}

Our study assessed the response of 2 Glycyrrhiza varieties (var. glabra and var. glandulifera) to callus induction under different growth conditions. The ability to form callus depended on the composition of growth media. Leaves of Glycyrrhiza were cultured on MS medium supplemented with different concentrations of auxins (2,4-D and NAA) and cytokinins (BA, Kin). The best conditions to induce callus were: MS medium supplemented with $(0.5 \mathrm{mg} / \mathrm{l}) 2,4-\mathrm{D}+(1 \mathrm{mg} / \mathrm{l}) \mathrm{NAA}+$ $(0.5 \mathrm{mg} / \mathrm{l}) \mathrm{Kin}$. 
Table 3. Effect of different hormones on the response of callus induction (\%) from leaves of two varieties of Glycyrrhiza glabra and means of callus fresh weight after four weeks

\begin{tabular}{c|c|c|c|c|c|c|c}
\hline \multicolumn{4}{c|}{$\begin{array}{c}\text { Growth regulators* } \\
{[\mathrm{mg} / \mathrm{l}]}\end{array}$} & \multicolumn{2}{c|}{$\begin{array}{c}\text { Callus induction \% } \\
{[\text { mean } \pm \text { SD] }}\end{array}$} & \multicolumn{2}{c}{$\begin{array}{c}\text { Mean fresh weight of callus } \\
{[\mathrm{g} / \text { explant, mean } \pm \text { SD] }}\end{array}$} \\
\hline NAA & $2,4-\mathrm{D}$ & Kin & BA & Var. Glandulifera & Var. Glabra & Var. Glandulifera & Var. Glabra \\
\hline 0 & 0 & 0 & 0 & 0 & 0 & 0 & 0 \\
\hline 1 & 0.5 & 0.5 & 0 & $100 \pm 0.00$ & $100 \pm 0.002$ & $2.17 \pm 0.072$ & $2.59 \pm 0.326$ \\
\hline 1 & 1 & 0.5 & 0 & $94.45 \pm 0.092$ & $100 \pm 0.005$ & $1.98 \pm 0.46$ & $2.60 \pm 0.314$ \\
\hline 0.5 & 0 & 0.5 & 2 & $75 \pm 0.184$ & $86.12 \pm 0.021$ & $1.46 \pm 0.47$ & $1.50 \pm 0.145$ \\
\hline 1 & 0 & 0 & 2 & $63.88 \pm 0.064$ & $75 \pm 0.017$ & $1.29 \pm 0.34$ & $1.06 \pm 0.122$ \\
\hline
\end{tabular}

* NAA ( $\beta$ - naphthalene acetic acid), 2,4-D (Dichlorophenoxy acetic acid), Kin (Kinetin), BA (Benzyl adenine)

Table 4. Polymorphic fragments of ISSR primers, the sizes of polymorphic PCR-products between licorice and callus

\begin{tabular}{|c|c|c|c|c|c|c|c|c|c|c|c|c|c|}
\hline \multirow{2}{*}{$\begin{array}{c}\text { Band } \\
\text { no. }\end{array}$} & \multirow{2}{*}{$\begin{array}{c}\text { Band } \\
\text { sizes } \\
{[\mathrm{bp}]}\end{array}$} & \multicolumn{4}{|c|}{ Primer 807} & \multicolumn{4}{|c|}{ Primer 823} & \multicolumn{4}{|c|}{ Primer 844} \\
\hline & & L1 & $\mathrm{C} 1$ & $\mathrm{~L} 2$ & $\mathrm{C} 2$ & $\mathrm{~L} 1$ & $\mathrm{C} 1$ & $\mathrm{~L} 2$ & $\mathrm{C} 2$ & L1 & $\mathrm{C} 1$ & $\mathrm{~L} 2$ & $\mathrm{C} 2$ \\
\hline 1 & 1223 & - & - & - & - & + & + & + & - & - & - & - & - \\
\hline 2 & 960 & - & - & - & + & - & - & - & - & - & - & - & - \\
\hline 3 & 914 & + & - & - & - & - & - & - & - & - & - & - & - \\
\hline 4 & 801 & - & - & - & - & - & - & + & + & - & - & - & - \\
\hline 5 & 785 & - & - & - & - & + & + & - & - & - & - & - & - \\
\hline 6 & 748 & - & - & - & - & - & & - & - & + & + & + & + \\
\hline 7 & 717 & + & + & - & - & - & - & - & - & - & - & - & - \\
\hline 8 & 702 & - & - & + & + & - & - & - & - & - & - & - & - \\
\hline 9 & 629 & - & - & - & - & - & - & - & - & + & + & - & - \\
\hline 10 & 587 & + & + & - & - & - & - & - & + & - & - & - & - \\
\hline 11 & 563 & - & - & - & - & - & - & - & - & - & - & - & + \\
\hline 12 & 490 & - & - & - & - & + & + & - & - & - & - & - & - \\
\hline 13 & 480 & - & - & + & + & - & - & - & - & + & + & - & - \\
\hline 14 & 470 & + & + & - & - & - & - & + & + & - & - & + & + \\
\hline 15 & 409 & - & - & - & - & + & + & - & - & - & - & - & - \\
\hline 16 & 392 & - & - & - & - & - & - & - & - & - & + & - & - \\
\hline 17 & 374 & + & + & + & + & - & - & - & - & - & - & - & - \\
\hline 18 & 344 & - & - & - & - & - & + & - & - & - & - & - & - \\
\hline 19 & 321 & - & - & - & - & - & - & + & + & - & - & - & - \\
\hline 20 & 306 & - & - & - & - & - & - & - & - & - & - & + & + \\
\hline 21 & 299 & - & - & - & - & - & + & - & - & + & + & - & - \\
\hline
\end{tabular}

L1 - Var. glandulifera, L2 - Var. glabra - plant, C1 - Var. glandulifera, C2 - Var. glabra - callus, presence (+) or absence $(-)$ of bands are indicated 
The results of experiments performed indicate that different plant growth regulating (PGRs) hormones had different effects on callus establishment. The combination effect of different concentrations of Kin, 2,4-D, BA and NAA on callus induced from leaves of 2 Glycyrrhiza glabra varieties are shown in Table 3 . The callus was produced from the explants after 4 weeks of culture in the dark. The darkness was beneficial for callus induction as it reduced callus browning and necrosis in comparison to light condition. The reasons for poor growth of calli under the light (change in color to brown and callus necrosis) were poly-phenolic compounds which inhibit callus growth. The phenolic compound accumulation and their oxidation which involves many toxic compounds resulting in cell necrosis (Khosroushahi et al., 2011). Glycyrrhiza plants contain many phenolic compounds that are effected by light and turn in to brown compounds, so the darkness was more effective in reducing browning of calli. As described in the previous studies by Poudyal and coworkers (2008) the dark treatment alone in the shoot tips of $P$. bretschneideri controlled the browning problem. According to Çördük and Aki (2011) the pre-culture in continuous dark was also effective to reduce the browning problem. Vijayalakshmi and Shourie (2016) suggested that the addition of antioxidants like ascorbic acid and citric acid to the medium was effective in reducing the browning of calli.

Data listed in Table 3 indicate that $100 \%$ of callus induction was achieved on a medium supplemented with different growth regulators (2,4-D $(0.5 \mathrm{mg} / \mathrm{l})$, NAA $(1 \mathrm{mg} / \mathrm{l})$ and $\mathrm{Kin}(0.5 \mathrm{mg} / \mathrm{l}))$. The percentages of callus induction when NAA $(1 \mathrm{mg} / \mathrm{l})$ was combined with BA $(2 \mathrm{mg} / \mathrm{l})$ were $63.88 \%$ for $G$. glabra var. glabra leaves and $75 \%$ in case of G. glabra var. glandulifera leaves. These results are in agreement with those of Wongwicha and coworkers (2008) who tested the licorice plants, Glycyrrhiza glabra, G. inflate and G. uralensis, for callus induction on MS medium combined with auxins and cytokinins. Their results showed that after 4 weeks of culture, $33-100 \%$ of leaf or stem explants formed calli. Al-Obaidi and coworkers (2012) found that the combination of $2.5 \mathrm{mg} / 12,4-\mathrm{D}$ and $0.5 \mathrm{mg} / \mathrm{l} \mathrm{BA}$ resulted in the best callus induction for both explants (male, female) of jojoba. In their study, callus induction percentage due to the interaction between the 2 growth regulators was $83.3 \%$. The combination of 2,4-D and kinetin was found to be effective in optimum callus induction in Aquilaria malaccensis Lam recorded by Saikia and coworkers (2013).

Other related study by Lalida and coworkers (2013) showed that callus of Moringa oleifera has been induced (100\%) on MS medium supplemented with 2,4-D $(0.5 \mathrm{mg} / \mathrm{l})$ and that the best concentration of auxin for the induction of callus varied according to the plant species and the nature of explant tissues. Abd El-kadder and coworkers (2014) investigated callus formation and production of phenols, flavonoids, and antioxidants by Dilleniaindica trees using tissue culture techniques. Their results indicated that callus cultured in a medium containing $2.0 \mathrm{mg} / 1 \mathrm{BAP}$ and $2.0 \mathrm{mg} / \mathrm{l} \mathrm{NAA}$ gave the highest callus formation, while medium with 2,4-D $(2.0 \mathrm{mg} / \mathrm{l})$ only produced the highest significant callus fresh weight.

Data presented in Table 3 also indicate that the highest callus fresh weight ( $2.17 \mathrm{~g} /$ explant) was obtained when leaves of var. glandulifera were cultured on MS medium with $0.5 \mathrm{mg} / 1$ 2,4-D, $0.5 \mathrm{mg} / \mathrm{l} \mathrm{Kin}$ and $1 \mathrm{mg} / 1$ NAA compared with the lowest (1.29 g/explant) fresh weight obtained on a medium supplemented with NAA $(1 \mathrm{mg} / \mathrm{l})$ and BA $(2 \mathrm{mg} / \mathrm{l})$. Meanwhile in vitro culture of var. glabra leaves gave the highest callus fresh weight ( $2.59 \mathrm{~g} /$ explant) on the medium containing $1 \mathrm{mg} / 1 \mathrm{NAA}$, $0.5 \mathrm{mg} / 1$ 2,4-D and $0.5 \mathrm{mg} / 1 \mathrm{Kin}$, but the lowest callus fresh weight (1.06 g/explants) was achieved on the medium containing $1 \mathrm{mg} / 1 \mathrm{NAA}$ in combination with $2 \mathrm{mg} / 1$ BA. The observed differences in the responses in callus induction between the 2 studied varieties at different media were not statistically significant.

\section{Molecular analysis}

To evaluate the genetic variation associated with callus induction ISSR technique was used. Somaclonal variation, a common phenomenon in plant cell cultures, includes all types of variations among plants or cells and is occurring in all kinds of tissue cultures (Skirvin et al., 1993). These changes, may vary according to species and include changes in chromosome number and/or structure, point mutations and changes in gene expression levels and patterns (Bordallo et al., 2004).

Among 10 primers used in this study for initial screening, 3 primers $(807,823$ and 488$)$ produced 21 polymorphic and monomorphic bands within 2 investigated varieties and from callus induced on MS medium supple- 


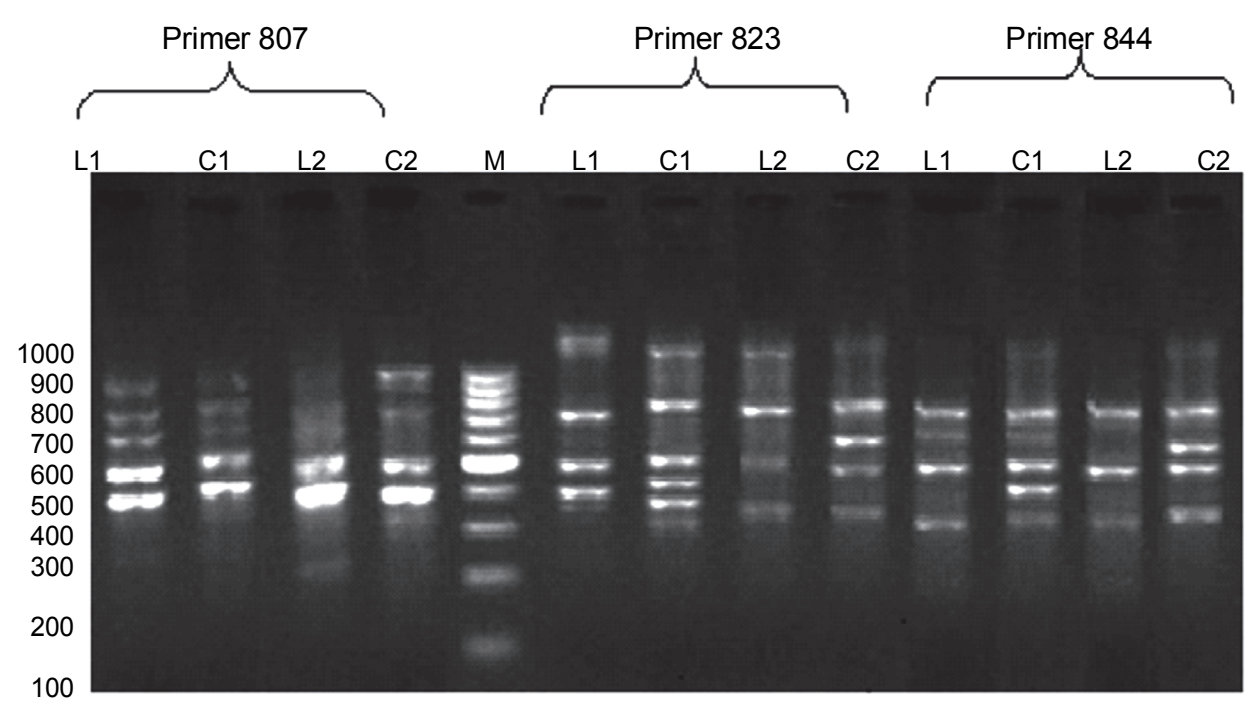

Fig. 1. ISSR pattern of licorice and calli with the primers indicated on the top of the figure M - marker from 1000 to 100 bp, L1 - Var. glandulifera, L2 - Var. glabra - plant, C1, C2 - callus

mented with $0.5 \mathrm{mg} / 1$ 2,4-D, $1 \mathrm{mg} / \mathrm{l} \mathrm{NAA}$ and $0.5 \mathrm{mg} / 1$ Kin (Fig. 1). The results of DNA fingerprints generated by PCR amplification using the 3 primers are presented in Table 4. The ISSR band number $3(914 \mathrm{bp})$ amplified by the primer 807 occurred only in a plant and was absent from callus of var. glandulifera, while band number 2 (960 bp) was amplified in callus and absent from a plant var. glabra. The ISSR band number 18 (344 bp) and a band number 21 ( $299 \mathrm{bp}$ ) amplified by the primer 823 were present in callus of var. glandulifera, while band number10 (587 bp) was amplified in callus and absent from plant var. glabra. The ISSR band number 16 (392 bp) amplified by the primer 844 was present in callus var. glandulifera, while band number 11 (563 bp) was detected in callus and absent from a plant var. glabra. Jarda and coworkers (2014) used 2 types of molecular markers, ISSR and multilocus simple sequence repeat (SSR) markers to determine the somaclonal variability of endemic taxa Dianthus giganteus subsp. Banaticus during in vitro culture, after a period of 24 months. The assessment of somaclonal variability showed some changes in the presence/absence of certain markers in some individuals. The Authors also found that ISSR markers were more polymorphic than SSR markers.

The presence of genetic variations at DNA level during in vitro culturing has been demonstrated in this study. These data are in agreement with previous study by Dakah and coworkers (2015) who determined the genetic relationship among 5 genotypes of Ziziphora ca- nescens Benth and of Ziziphora tenuior L. grown in Syria. The Authors evaluated the genetic stability of in vitro plants and compared it with wild-type plants. The calli from Ziziphora tenuior L. induced on different media (MS $+0.5 \mathrm{mg} / 1 \mathrm{Kin}+1.5 \mathrm{mg} / 1 \mathrm{NAA}$ or MS + $0.5 \mathrm{mg} / \mathrm{l} \mathrm{Kin}+2 \mathrm{mg} / \mathrm{l} \mathrm{IBA}$ ) exhibited higher genetic variations as determined using ISSR and RAPD markers, compared with micropropagated plants from apical meristems induced on MS + $1 \mathrm{mg} / \mathrm{l} \mathrm{NAA}+1 \mathrm{mg} / \mathrm{l} \mathrm{Kin} \mathrm{media.}$ Genetic changes occur due to genome rearrangements during early culturing, when cells are under stress and adapt surviving in the new environment.

The obtained results clearly indicated the occurrence of genetic variations at the DNA level emerging during in vitro cultures (Fig. 1). Molecular markers like ISSR can be used to evaluate the genetic variations occurring during in vitro cultures. These results may be due to chemical modification of culture media like the presence of different concentrations of growth regulators causing stress on callus, leading to the genetic variations. Our results are in agreement with those by Singh and coworkers (2013) who explained that the genetic variation in DNA may be due to naturally occurring variations or hormonal balance, in vitro stress induced by adding biochemical or other nutritional conditions. According to Cassells and Curry (2001) in vitro conditions (particularly callus induction) induces physiological stress, which may be characterized by disruption of normal developmental controls and the occurrence of somaclonal varia- 
tion due to the pre-adapted cellular responses to stress. Saker and coworkers (2000) and Dakah and coworkers (2015) reported that the variations during in vitro culture of plants can happen due to different reasons such as gene amplification, modifications in DNA methylation, chromosomal abnormality and point mutation. The results obtained by Dakah and coworkers (2015) indicated that changes of the media of plant tissue culture, salinity and $\mathrm{pH}$ led to higher polymorphism especially in callus media.

\section{Conclusions}

Through in vitro culture genetic variations at several occur at DNA level and such genomic rearrangements lead to genetic changes of plant material. ISSR marker technique can be used for detection of the genetic variations during in vitro cultures. The plant growth regulating (PGRs) hormones had different effects on callus establishment. The best conditions to induce callus were as follows: MS medium containing 2,4-D in combination with NAA and Kin. Callus induction was obtained for 2 varieties of Glycyrrhiza glabra without browning under dark conditions. The protocol presented the best callus growth which will be used in the future studies as a source for production of secondary metabolites from medicinal plants.

\section{References}

Abd El-Kadder E.M., Lashin I.I., Aref M.S., Hussian E.A., Ewais E.A. (2014) Physical elicitation of Dilleniaindica callus for production of secondary metabolites. New York Sci. J. 7(10): 48-57.

Abirami H., Kumar P.S. (2013) In vitro regeneration and extraction of secondary metabolites in Aegle marmelos (L.) Correa. Asian J. Plant Sci. Res. 3(2): 99-106.

Al-Obaidi J.R., Suliman B.K., Al-Ani N.K. (2012) Molecularbased marker for sex differentiation of jojoba in vivo and in vitro Iraqi cultivars using RAPD- PCR technique. Sci. Res. Essays 7(4): 522-527.

Bennet A., Melhuish P.B., Stanmford I.F. (1985) Carbenoxolone and deglycyrrhized liquorice have little or no effect on prostanoid synthesis by rat gastric mucosa ex vivo. $\mathrm{Br}$. J. Pharmacol. 86: 693-695.

Bordallo P.N., Silva D.H., Maria J., Cruz C.D., Elizabeth P., Fontes E.P. (2004) Somaclonal variation on in vitro callus culture potato cultivars. Horticul. Brasil. 22(2): 300-304.

Cassells A.C., Curry R.F. (2001) Oxidative stress and physiological, epigenetic and genetic variability in plant tissue culture: implications for micropropagators and genetic engineers. Plant Cell Tiss. Organ Cult. 64: 145-157.
Çördük N., Aki C. (2011) Inhibition of browning problem during micropropagation of Sideritis trojana bornm. an endemic medicinal herb of Turkey. Roman. Biotech. Lett. 16(6): 6760-6765.

Dakah A., Suleiman M., Zaid S. (2015) Genetic relationship among wild medicinal genotypes of Ziziphora canescens Benth. and Ziziphora tenuior L. and detection of genetic variations resulted from tissue culture, salinity and $\mathrm{pH}$ media. Amer. J. Agricult. Biol. Sci. 10(3): 144-156.

Duncan D.B. (1955) Multiple range and multiple F-test. Biometrics 11: 1-42.

Habibi N., Suthar R.K., Purohit S.D. (2009) Role of PGrs and inhibitors in induction and control of somatic embryogenesis in Themeda quadrivalvis. Indian J. Exp. Biol. 47: 198-203.

Jarda L., Butiuc-keul A., Höhn M., Pedryc A., Cristea V. (2014) Ex situ conservation of Dianthus giganteusd'Urv. subsp. banaticus (Heuff.) Tutin by in vitro culture and assessment of somaclonal variability by molecular markers. Turk. J. Biol. 38: 21-30.

Khosroushahi A.Y., Manesh H.N., Simonsen H.T. (2011) Effect of antioxidants and carbohydrates in callus cultures of Taxus brevifolia: evaluation of browning, callus growth, total phenolics and paclitaxel production. Bioimpacts 1: 37-45.

Koga K., Takekoshi K., Kawashima S., Taniguchi M., Murakami M. (2004) Clove oil prevents Glycyrrhizin gel formation in aqueous solution. Chem. Pharm. Bull. 52: 1507-1510.

Kondo K., Mao S.B., Hiroki Y., Takashi M., Cheng Z.M., Pan H.X. et al. (2007) Species identification of licorice using nrDNA and cpDNA genetic markers. Biol. Pharmceut. Bull. 30: 1497-1502.

Lalida P.S., Rithayong T., Lee V.S., Dheeranupattana S. (2013) Peroxidase activity in native and callus culture of moringa Oleifera Lam. J. Med. Bioeng. 2(3): 163-167.

Mokhtari A., Otroshy M., Barekat T. (2015) Plant regenerationthrough callusinduction on medicinal herb Viola odorata- role of plant growth regulator and explants. Agr. Forest 61: 191-170.

Murashige T., Skoog T. (1962) A revised medium for rapid growth and bioassays with tobacco tissue cultures. Phsiol. Plant 15: 473-497.

Niu C., Kebedel H., Dick L., Auld D.L., Woodward J.E., Burow G., Wright R.J. (2008) A safe inexpensive method to isolate high quality plant and fungal DNA in an open laboratory environment. Afr. J. Biotech. 7(16): 2818-2822.

Poudyal B.K., Du G., ZhangY., LiuJ., Shi Q. (2008) Studies on browning problem and phenols content on shoots of Yali, Aikansui and Abbe Fetel pears for in vitro culture. Front. Agric. China 2(3): 321-330.

Saikia M., Shrivastava K., SinghS.S. (2013) Effect of culture media and growth hormones on callus induction in Aquilaria malaccensis Lam., a medicinally and commercially important tree species of North East India. Asian J. Biol. Sci. 6(2): 96-105. 
Saker M.M., Bekheet S.A., Taha H.S., Fahmy A.S., Moursy H.A. (2000) Detection of somaclonal variations in tissue culture-derived date palm plants using isoenzyme analysis and RAPD fingerprints. Biol. Plant. 43: 347-351.

Shibata S.A. (2000) Drug over the millennia: pharmacognosy, chemistry, and pharmacology of licorice. Yakugaku Zasshi. 120: 849-862.

Singh S.R., Dalal S., Singh R., Dhawan A.K., Kalia R.K. (2013) Evaluation of genetic fidelity of in vitro raised plants of Dendrocalamus asper (Schult. \&Schult. F.) Backer ex K. Heyne using DNA-based markers. Acta Physiol. Plant. 35: 419-430.

Skirvin R.M., Norton M., Mcpheeters K.D. (1993) Somaclonal variation: has it proved useful for plant improvement?Acta Horticult. 336: 333-340.
Kondo K., Shiba M., Yamaji H., Morota T., Zhengmin C., Huixia P., Shoyama Y. (2007) Species identification of licorice using nrDNA and cpDNA genetic markers. Biol. Pharm. Bull. 30: 1497-1502.

Vijayalakshmi U., Shourie A. (2016) Remedial effect of ascorbic acid and citric acid on oxidative browning of Glycyrrhizaglabra callus cultures. BioTechnologia 97(3): 179-186.

Wongwicha W., Tanaka H., Shoyama Y., Tuvshintogtokh I., Putalun W. (2008) Production of Glycyrrhizin in callus cultures of Licorice. Z. Naturforsch. 63: 413-417.

Yano S., Harada M., Watanabe K., Hatakeyama Y., Shibata S., Takahashi K. (1989) Antiulcer activities of glycyrrhetinic acid derivatives in experimental gastric lesion models. Chem. Pharm. Bull. 37: 2500-2504. 